\title{
Hearing Impairment
}

National Cancer Institute

\section{Source}

National Cancer Institute. Hearing Impairment. NCI Thesaurus. Code C50576.

Partial or complete loss of the ability to detect or understand sounds resulting from damage to the outer, middle, or inner ear structures. Causes include exposure to loud noise, ear infections, injuries to the ear, genetic, and congenital disorders. 